\title{
Estimation of Variability and Genetic Parameters in Indica and Japonica Genotypes of Rice (Oryza sativa L.)
}

\author{
K. Parimala ${ }^{1}$ and K. Rukmini Devi ${ }^{2}$ \\ ${ }^{1}$ Seed Research and Technology Centre, PJTSAU, Rajendranagar, Hyderabad- 500 030, India \\ ${ }^{2}$ Regional Agricultural Research Station, PJTSAU, Warangal - 506 007, India \\ *Corresponding author
}

\begin{tabular}{|l|}
\hline Key w or d s \\
Rice, PCV, GCV, \\
heritability, Genetic \\
advance
\end{tabular}

A B S T R A C T

A study was undertaken to study the extent of variability and genetic parameters with seven parents and 21 crosses for seven traits in rice. Higher estimates of GCV and PCV were recorded for pollen fertility (\%) and grain yield per plant suggested that these traits can be improved through simple selection. High heritability coupled with high genetic advance was observed for plant height, pollen fertility (\%), panicle length, number of filled grains per panicle and grain yield per plant and it reveals the preponderance of additive gene action. Selection is effective based on phenotypic values for further improvement of these traits. The significant estimates of genetic component of variation due to additive (D) and dominant components $\left(\mathrm{H}_{1}\right.$ and $\left.\mathrm{H}_{2}\right)$, reveals the importance of both additive and dominant genes for the traits studied. Positive value of ' $F$ ' exhibited greater proportion of dominant alleles for all the traits and it indicates the asymmetric gene distribution. Mean degree of dominance $\left(\mathrm{H}_{1} / \mathrm{D}\right)^{1 / 2}$ was found to be more than unity for all the traits which reveals the presence of over dominance. The higher proportion of dominant alleles in parents was evident from the positive value of ' $F$ ' for all the traits studied except for grain yield per plant. The traits, days to $50 \%$ flowering, plant height, pollen fertility (\%), panicle length, number of filled grains per panicle and grain yield per plant were controlled by additive gene action, which could be improved through simple selection methods.

\section{Introduction}

Rice is the most important food crop for more than one third of world's population (Singh and Singh, 2008). In view of the growing population, the basic objective of the plant breeders would always be towards yield improvement in staple food crops. Development of high yielding varieties requires the information of existing genetic variability. Evaluation of rice germplasm for yield and its component traits is an important aspect of crop improvement programme. Success of any plant breeding programme depends on availability of information on nature and magnitude of gene action involved in the inheritance of character. Knowledge on genetic parameters is useful in detecting the amount of variability present in the genotypes. Evaluation of extent of heritable variation is 
important to understand the potential of genotypes for use in breeding programme. Heritability coupled with high genetic advance would be more useful tool in predicting the resultant effect in selection. Keeping this in view, the present investigation was undertaken to study the genetic parameters for grain yield and its component traits in rice genotypes.

\section{Materials and Methods}

In the present study seven rice genotypes including four japonicas (Gedonzipetan, Mazila, Betagomblin and Orumundakan) and three indicas (BPT-5204, Kavya and MLTSG-278) were selected on the basis of their diversity for various quantitative characters and crossing were made in all possible combinations except reciprocals. Thus the experimental material comprised of $21 \mathrm{~F}_{1} \mathrm{~s}$ and their seven parents were evaluated at Regional Agricultural Research Station, Warangal in Randomized Block Design with three replications. Single seedling per hill was planted to raise the healthy crop.

Each entry was planted in a single row of $5 \mathrm{~m}$ length with a spacing of $20 \times 15 \mathrm{~cm}$. All recommended cultural practices were followed to obtain normal growth of the crop. Observations were recorded on ten plants selected randomly from each row. Data was collected on seven characters viz., days to $50 \%$ flowering, plant height $(\mathrm{cm})$, number of effective tillers per plant, pollen fertility (\%), panicle length $(\mathrm{cm})$, number of filled grains per panicle and grain yield per plant $(\mathrm{g})$. The mean values of all these traits were used for estimation of genetic parameters as suggested by Hayman (1954). The phenotypic coefficient of variation (PCV) and genotypic coefficient of variation (GCV) was calculated by the formulae given by Burton (1952). Broad sense heritability and genetic advance were estimated as suggested by Johnson et al., (1955).

\section{Results and Discussion}

Phenotypic variance was slightly higher than the genotypic variances for all the traits (Table 1). The difference between phenotypic coefficient of variation (PCV) and genotypic coefficient of variation (GCV) for the traits studied was very low. It indicates that the influence of environment on the expression of these traits is very little. Higher estimates of PCV and GCV were recorded for pollen fertility (\%) and grain yield per plant and it suggest that simple selection can be followed for further improvement of these traits. Kundu et al., (2008), Rema Bai et al., (1992) also found higher estimates of GCV and PCV for grain yield. The traits, plant height (12.51), number of effective tillers per plant (13.62), panicle length (18.62) and number of filled grains per panicle (15.45) exhibited moderate values of PCV and GCV. Low variability was observed for days to $50 \%$ flowering which is due to narrow genetic base of parents.

The estimate of heritability is a good index to study a transmission of characters from parents to its progeny. High heritability estimates were recorded for all the traits suggested that these traits would respond to selection due to their high genetic variability and transmissibility. Similar findings were reported by Verma (2010), Anandarao et al., (2011), Sangam Kumar Singh et al., (2011) and Lingaiah et al., (2014). High heritability coupled with high genetic advance which was mainly attributed due to additive gene action with respect to the traits viz., plant height, pollen fertility (\%), panicle length, number of filled grains per panicle and grain yield per plant. It provided a greater scope for selection and further improvement. This suggested the presence of fixable component of genetic variation for these traits. Mass selection based on phenotypic values can be useful for improving these traits. 
Table.1 Components of genetic parameters for different traits in rice

\begin{tabular}{|l|c|c|c|c|c|c|}
\hline \multicolumn{1}{|c|}{ Character } & Mean & PCV & GCV & Heritability & $\begin{array}{c}\text { Genetic } \\
\text { advance }\end{array}$ & $\begin{array}{c}\text { Genetic advance } \\
\text { over mean }\end{array}$ \\
\hline Days to 50\% flowering & 107.95 & 6.77 & 6.71 & 98.1 & 14.63 & 13.55 \\
\hline Plant height & 116.05 & 12.51 & 12.25 & 95.8 & 28.04 & 24.16 \\
\hline No. of effective tillers / plant & 14.10 & 13.62 & 11.49 & 71.1 & 2.38 & 16.87 \\
\hline Pollen fertility (\%) & 73.85 & 21.53 & 20.37 & 89.5 & 27.72 & 37.53 \\
\hline Panicle length & 20.10 & 18.62 & 18.45 & 98.2 & 7.50 & 37.31 \\
\hline No. of filled grains / panicle & 182.09 & 15.45 & 15.08 & 95.2 & 53.85 & 29.57 \\
\hline Grain yield / plant & 46.16 & 29.22 & 29.09 & 99.1 & 27.41 & 59.38 \\
\hline
\end{tabular}

Table.2 Estimates of genetic parameters for seven characters in rice

\begin{tabular}{|c|c|c|c|c|c|c|}
\hline Character & D & $\begin{array}{l}\wedge \\
\mathbf{F}\end{array}$ & $\begin{array}{r}\wedge \\
H_{1}\end{array}$ & $\begin{array}{c}\hat{\wedge} \\
\mathbf{H}_{2}\end{array}$ & $\hat{h^{2}}$ & $\hat{\mathbf{E}}$ \\
\hline Days to $50 \%$ flowering & $100.01 * *$ & $75.49 * *$ & $136.91 * *$ & $113.39 * *$ & $27.39 * *$ & 0.38 \\
\hline Plant height & $180.71 * *$ & $208.44 * *$ & $786.66 * *$ & $584.11 * *$ & $49.94 * *$ & $2.92 * *$ \\
\hline No. of effective tillers / plant & $1.90 * *$ & $1.61 * *$ & $10.21 * *$ & $8.01 * *$ & -0.19 & 0.46 \\
\hline Pollen fertility (\%) & $383.49 * *$ & $146.99 * *$ & $394.33 * *$ & $319.67 * *$ & $125.45 * *$ & $9.27 * *$ \\
\hline Panicle length & $22.29 * *$ & $11.49 * *$ & $28.93 * *$ & $24.85 * *$ & $24.10 * *$ & 0.10 \\
\hline No. of filled grains / panicle & $757.99 * *$ & $825.67 * *$ & $2841.10 * *$ & $2081.72 * *$ & $9.76^{* *}$ & $13.17 * *$ \\
\hline Grain yield / plant & $145.47 * *$ & $24.84 * *$ & $423.60 * *$ & $353.20 * *$ & $71.19 * *$ & 0.53 \\
\hline
\end{tabular}

Table.3 Ratios of genetic parameters for seven characters in rice

\begin{tabular}{|l|c|c|c|c|c|c|}
\hline \multicolumn{1}{|c|}{ Character } & $\left.\mathbf{( H}_{\mathbf{1}} / \mathbf{D}\right)^{\mathbf{1 / 2}}$ & $\mathbf{H}_{\mathbf{2}} / \mathbf{4 H}_{\mathbf{1}}$ & $\begin{array}{c}\mathbf{( 4 D H}_{\mathbf{1}} \mathbf{1}^{\mathbf{1 / 2}} \mathbf{+ F /} \\
\mathbf{( 4 D H}_{\mathbf{1}}^{\mathbf{1 / 2}} \mathbf{- F}\end{array}$ & $\mathbf{h}^{\mathbf{2} / \mathbf{H}_{\mathbf{2}}}$ & YD & YR \\
\hline Days to 50\% flowering & 1.17 & 0.21 & 1.95 & 0.24 & 78.24 & 84.69 \\
\hline Plant height & 2.09 & 0.19 & 1.76 & 0.09 & 112.74 & 115.123 \\
\hline No. of effective tillers / plant & 2.32 & 0.20 & 1.45 & -0.03 & 14.32 & 14.23 \\
\hline Pollen fertility (\%) & 1.01 & 0.20 & 1.47 & 0.39 & -202.46 & -191.31 \\
\hline Panicle length & 1.14 & 0.21 & 1.58 & 0.97 & 19.37 & 19.48 \\
\hline No. of filled grains / panicle & 1.94 & 0.18 & 1.78 & 0.01 & 98.46 & 154.75 \\
\hline Grain yield/ plant & 1.71 & 0.21 & 0.90 & 0.20 & -46.02 & -9.62 \\
\hline
\end{tabular}


Sangam Kumar Singh et al., (2011) was reported the high heritability with high genetic advance for plant height and number of filled grains per panicle. High heritability with medium genetic advance over mean was observed for days to $50 \%$ flowering and number of effective tillers per plant.

The significant estimates of genetic component of variation due to additive (D) and dominant components $\left(\mathrm{H}_{1}\right.$ and $\left.\mathrm{H}_{2}\right)$, reveals the importance of both additive and dominant genes for the traits studied (Table 2). This was in conformity with results of Narasimman et al., (2007) and Senthil Kumar (2011). Higher values of $\mathrm{H}_{1}$ and $\mathrm{H}_{2}$ than $\mathrm{D}$, indicates the genes with dominance properties appeared to be more pronounced. Distribution of more dominant alleles for all the traits was evidence from significant positive value of ' $F$ ' and it shows the asymmetric gene distribution. Net dominance effect obtained by $h^{2}$ estimate expressed as algebraic sum over all loci in heterozygous condition was significant for all the characters except for effective tillers per plant and suggested that substantial contribution of dominance was not due to heterogeneity of loci. The nonsignificance of environmental component of variation (E) for days to $50 \%$ flowering, effective tillers per plant, panicle length and grain yield per plant revealed its insignificant role in the phenotypic expression of these traits.

Mean degree of dominance $\left(\mathrm{H}_{1} / \mathrm{D}\right)^{1 / 2}$ was more than unity for all the traits reveals the existence of over dominance (Table 3). The asymmetric distribution of positive and negative alleles in the parents was evident from the value of $\mathrm{H}_{2} / 4 \mathrm{H}_{1}$, which was less than the maximum value of 0.25 for traits studied. The greater proportion of dominant alleles in parents $\left[\left(4 \mathrm{DH}_{1}\right)^{1 / 2}+\mathrm{F} /\left(4 \mathrm{DH}_{1}\right)^{1 / 2}-\mathrm{F}\right]$ was found for all the traits except for grain yield per plant $(0.90)$.
From the study, it was concluded that high heritability coupled with high genetic advance was mainly attributed due to additive gene action with respect to the traits such as plant height, pollen fertility (\%), panicle length, number of filled grains per panicle and grain yield per plant, which could be improved through simple selection methods.

\section{References}

Anandrao, S.D., Singh, C.M. Suresh, B.G. and Lavanya, G.R., 2011, Evaluation of rice hybrids for yield and yield component characters under North East Plain Zone. The Allahabad Farmer., 67(1): 63-68.

Burton, G.W., 1952, Quantitative inheritance in grasses. Proc. of $6^{\text {th }}$ Int. Grassland Congress Ames, Iowa, USA. p. 227283.

Hayman, B.I., 1954, The theory and analysis of diallel crosses. Genetics, 39:789809.

Johnson, H.W., Robinson, H.F. and Comstock, R.E., 1955, Estimates of genetic and environment variability in soybean. Agro. Journal 47: 314-318.

Kundu, A., Senapati, B.K. Bakshi, A. and Mandal, G.S., 2008, Genetic variability of panicle characters in tall indica aman rice. Oryza., 45(4): 320323.

Lingaiah, N., Venkanna V. and Cheralu. C. 2014. Genetic Variability Analysis in Rice (Oryza sativa L.). Int. J. Pure App. Biosci. 2 (5): 203-204.

Narasimman, R., Thirugnana Kumar, S. Senthil Kumar, N. Eswaran, S. and Praveen Sampath Kumar, C., 2007, Genetic analysis for grain yield and other morphological characters in rice (Oryza sativa). Crop Improvement, 34(2): 153-156.

Rema Bai, N., Regina, A. Devika, R. and Joseph, C.A., 1992, Genetic variability 
and association of characters in medium duration rice genotypes. Oryza, 29: 19-22.

Sangam Kumar Singh, Chandra Mohan Singh and Lal, G.M., 2011, Assessment of genetic variability for yield and its component characters in rice (Oryza sativa L.). Research in Plant Biology, 1(4):73-76.

Senthil Kumar, N., 2011, Genetics of grain yield and its component characters in rice. Crop Improv. 38(1): 45-47.
Singh, Y. and Singh, U.S., 2008, Genetic diversity analysis in aromatic rice germplasm using agro- morphological traits. Journal of Plant Genetic Resources, 21(1): 32-37.

Verma, U., 2010, Genetic diversity analysis in exotic rice germplasm. M. Sc. Thesis, SHIATS, Allahabad (India).

\section{How to cite this article:}

Parimala, K., and Rukmini Devi, K. 2019. Estimation of Variability and Genetic Parameters in Indica and Japonica Genotypes of Rice (Oryza sativa L.). Int.J.Curr.Microbiol.App.Sci. 8(03): 1138-1142. doi: https://doi.org/10.20546/ijcmas.2019.803.135 